\title{
Crypt Burials from the Cloister Church of Riesa (Germany) - Changes of Funerary Customs, Body Treatment, and Attitudes to Death
}

\section{Introduction}

The city of Riesa (Saxony, Germany) is located on the Elbe River, approximately $50 \mathrm{~km}$ northwest of Dresden. Between IIII and III9, a monastery was founded on the Elbe shore and was later transformed into a Benedictine nuns' convent in the $13^{\text {th }}$ century (Ender et al. 2007: 15; Dannenberg, Westphalen 2019: 231). After the secularization in 1540 , the convent became part of Riesa manor. The owners of Riesa manor were local noble families who used the cloister church as patronage church and burial place. Several epitaphs and tombstones within the church attest to their presence.

The oldest crypt is located in the northern annexe to the nave right below the patronage lodge (Fig. I) and was used from 1595 onwards by the families von Embden and Bock as burial place (Gurlitt 1914: 120). This vault was evicted in the following centuries, therefore no remains from this crypt are preserved today. The biggest and most important crypt for this study is the one below the altar, a groined vault with a size of circa $32 \mathrm{~m}^{2}$ and with two opposite openings for ventilation (Fig. 2 ). Nowadays, a staircase, emerging behind the altar, grants access to the crypt while in the past, there has been an additional sinkhole through which the coffins could be brought into the vault. The crypt was erected from quarrystones, bricks and Elbe sandstone, probably right after Christoph von Felgenhauer (II) (I577-I639) had purchased Riesa manor in 1622. His surname Felgenhauer (English: wheelwright) reveals 


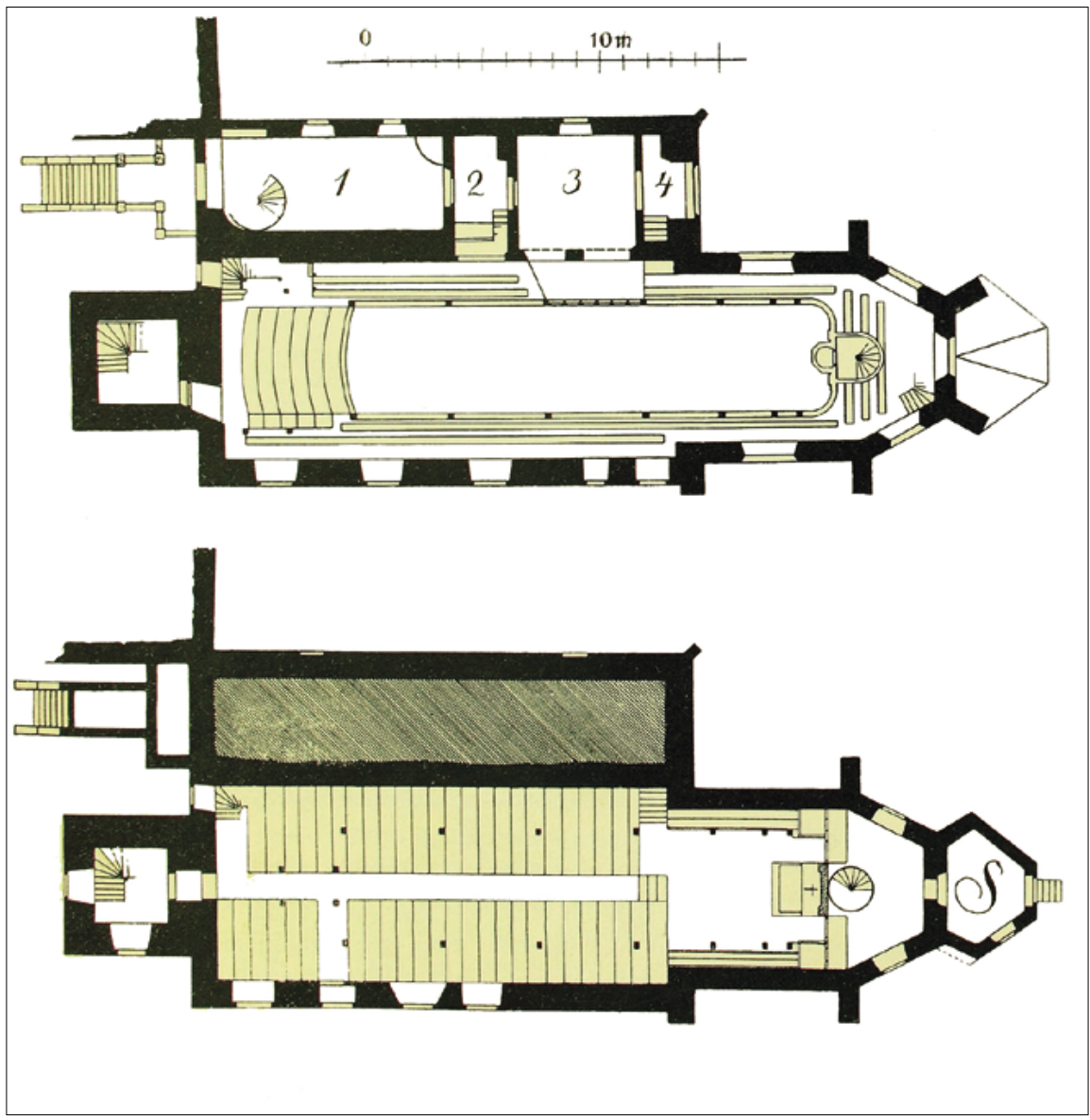

Fig. 1. Floor plan of Riesa cloister church with first gallery (top) and nave (bottom), situation prior to 1909. The crypt below the altar is situated underneath the choir. The northern crypt is located on the ground floor below rooms 3 and 4, the Embden crypt below room I. Figure modified after Gurlitt 19I4, fig. I56-I57.

their common origin as craftsmen. The purchase was a step in the orchestration of the family as being of noble origin with a long history, even by inventing a noble genealogy (von Uechtritz 1792: 136-I44; von Feilitzsch 1896: 70-74). In fact, Christoph von Felgenhauer (II) was a commoner who made career under the Electors of Saxony and was ennobled in 1624 (Donath 2019: 244). Riesa manor became the family estate of von Felgenhauer and soon received market rights, resulting in the flourishing of the city. Besides, the family held a second estate at Hirschstein Castle. During their regime, the family used the former cloister church as patronage church and burial place (Gurlitt 1914: I20). The descendants of Christoph von Felgenhauer (II) held 
Riesa manor until 1716 , afterwards the estate was acquired by councilor of commerce Johann Christoph Hanisch (1708-1774) whose descendants were ennobled in 1790 as the barons von Odeleben. Due to severe indebtedness, Riesa manor was placed under sequestration in 1813 , from which Curt Robert Freiherr von Welck (1798-1866) purchased it in 1824 . In 1828 , following his curiosity, the new estate owner opened the sealed crypt below the altar and arranged for an official documentation of the crypt's content (Thomas 1928; Voigtländer 186I). He decided in 1856 to found a new crypt for himself and his family (von Welck 1992: 164, 169; von Welck 2019: 249). This barrel vault is located in the northeastern corner of the annexe and is nowadays referred to as the "northern crypt" (Fig. I).

In the crypt below the altar, Curt Robert Freiherr von Welck observed a total of so coffins, among them larger adult and smaller children coffins, piled up into three stacks (von Welck I828). Together with a local priest and a physician, they opened all the coffins and described the clothing and state of preservation of the deceased as well as the presence of possible grave goods. Due to the ventilation, several bodies were preserved as mummies of leathery appearance, sometimes still with hair. 20 less well-preserved coffins were subsequently removed from the crypt and transported to a space between the annexe crypts from where their remains came again to light during construction works in 1984 and 2009 . The 30 remaining coffins in the crypt below

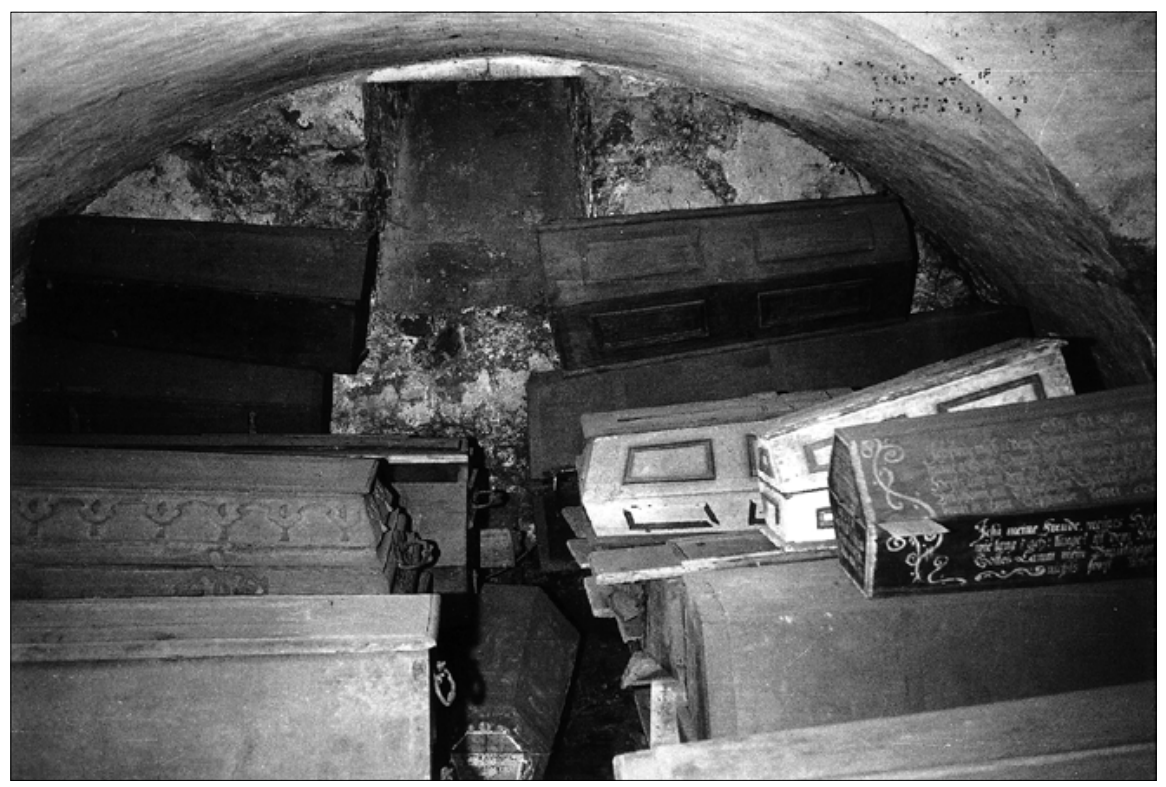

Fig. 2. View into the crypt below the altar in 1974 prior to the museal presentation. Due to space constraints, the coffins were placed on top of each other. Note the ventilation opening (photograph by M. Dietrich). 
the altar were numbered and information regarding the coffin (color, material, and decoration), the deceased, the state of preservation and the year of death (if available) recorded. Two side chambers to the crypt below the altar had already been opened in I8II and could be attributed to Dr. Georg Abel Ficker (I583-1652) and Christoph von Felgenhauer (III) (I608-1679) and their respective wives (Voigtländer I86I).

The official documentation from I 828 constitutes the background for the current identification of the burials, even though they were later affected by multiple changes resulting in the current appearance. In 1923 , several objects, especially funerary wreaths, were removed from the coffins and brought to the local history museum. In order to achieve a respectful display, the crypt was cleaned, and corpses were put back in (their) coffins and covered with linen sheets between 1974 and 1978 (Fig. 2). The glass covers and lighting originate from this period (Fig. 3 ) to grant the public temporary access to the crypt. However, despite the partial eviction and rearrangement of the interments, the inventory is far less disturbed than in other crypts since the translation of the remains was performed under careful consideration of the original setting. In addition, historical sources, such as the church register as well as family chronicles and later correspondence and photographs, allow us to reconstruct the changes, which the crypts underwent during time (Ströbl 2009).

With permission of the State Heritage Office of Saxony, the authors have conducted a thorough documentation and scientific analysis of the preserved coffins and coffin contents between 2016 and 2018 (Alterauge, Hofmann 2019). The research was only possible with the generous support of the Protestant-Lutheran parish of Riesa, who granted access to the crypts and provided the facilities for the investigations.

The aim of the project was to inventory the preserved remains at several locations in the cloister church which not only included the crypt below the altar and the northern crypt, but also findings formerly originating from the crypts and currently stored at the attics. The documentation and scientific analyses, which are still ongoing, have provided and will provide many insights into early modern funerary practices. We can retrieve information on wealth, social status, familial structures, infant mortality, piety, and faith of three ennobled Protestant families as well as individual fates from early $17^{\text {th }}$ to late $19^{\text {th }}$ century.

\section{Material and methods}

The cloister church has yielded different burial assemblages:

Crypt below the altar:

- Remains of the 30 coffins labelled and described in I828 (von Welck I828). Most of these coffins and mummified bodies are still located in the crypt below the altar (Fig. 3). This study focuses on these remains since the original context is mostly still preserved. 
- Remains of the 20 coffins translated in 1828 to the former Embden crypt. Wooden coffin planks, grave goods, textiles (mostly clothing) and skeletonized human remains are stored at the attic as well as in the side chambers of the crypt below the altar.

- Funerary objects, especially i2 funerary crowns, in the collection of the City Museum of Riesa (Lippok 2019).

Northern crypt:

- Five coffins in the northern crypt containing human mummified or skeletonized remains (Fig. 4). Burials of the family von Welck. The coffins were labelled with "N" plus a number to distinguish them from the coffins in the crypt below the altar.

- Remains of three coffins originating from the northern crypt at the attic.

Prior to the documentation, an investigation protocol was developed to limit movements of the coffins and human remains to the necessary minimum. All researchers were wearing protective clothing (masks, gloves, over-suit), and indoor climate was recorded through temperature and humidity data logger.

Every coffin was described, photographed, and measured, and isolated coffin planks were assembled according to their size, appearance and furnishing. If the

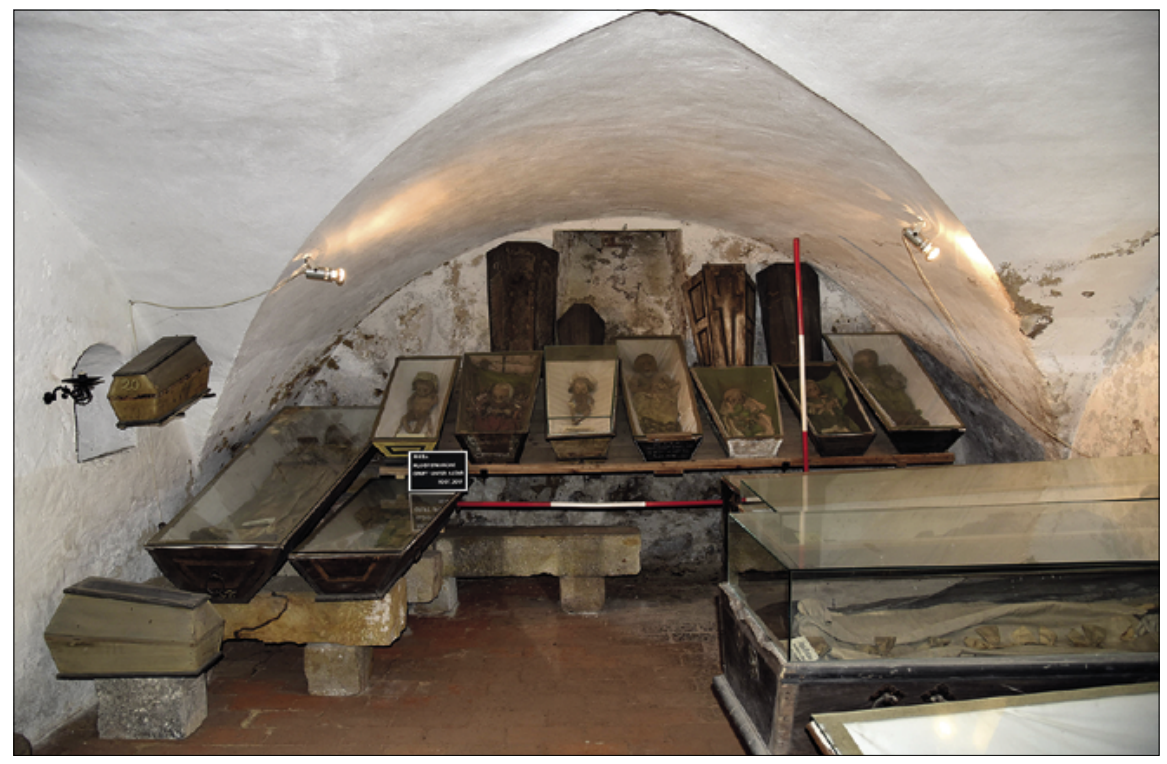

Fig. 3. Condition of the crypt below the altar in 2017, view to the southern corner with the children coffins. The glass covers and lighting were first established in 1978 (photograph by A. Alterauge). 


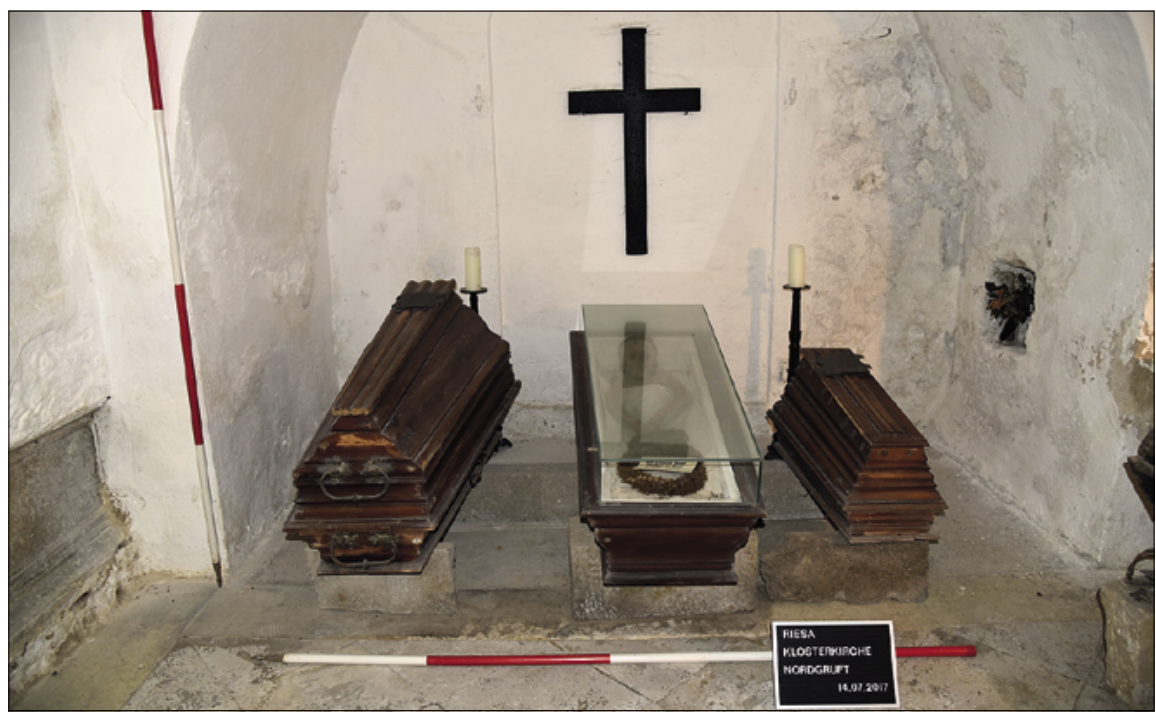

Fig. 4. Children coffins from the northern crypt, condition in 20I7. From right to left: coffin NI, N2, N3. Note the visibility of the naked wood, the elevated coffin lid and the fluted side plates (photograph by A. Alterauge).

coffin did not yield a date of death, it was dated according to the typo-chronology of Ströbl (20I4). Whenever possible, material and construction technique were noted, as well as the presence of other particularities (e.g., locks). The coffin furnishing was recorded so far it was visible. It included the coffin padding and the upholstery on which the deceased was lying. Coffin inscriptions were transliterated using the original spelling and indication of the Bible's book, chapter, and verse.

All coffins with human remains were $\mathrm{X}$-rayed on site with a mobile X-ray device (Examion ${ }^{\circ} \mathrm{PX}-20 \mathrm{BT}$ Plus X-ray generator, Examion ${ }^{\circ} \mathrm{X}$-DR portable detector) in anteroposterior and/or lateral projection. The bodies were left in place during the $\mathrm{X}$-ray examination. This approach turned out to be very advantageous since the $\mathrm{X}$-ray images do not only reveal any metal components of the coffin construction (e.g., nails) (Herrmann et al. 1990: 207-212), but also helped in deciphering the inscriptions made of lead paint. The textile and costume analyses were performed by conservators from the Museums of the City of Dresden. A visual inspection of the textiles revealed the style, cut, fashion, function, and material of the clothing as well as of footwear, stockings, gloves, bonnets and bands (Hofmann 2009; 2010). In a second step, assumptions on the functionality and dating of the clothing were made, which also benefited from the $\mathrm{X}$-ray images due to the depiction of haberdasheries. Besides, the conservators undertook the challenging task of sorting, documenting and flattening textile fragments from the church's attic. 
All bodies underwent a morphological investigation to estimate age, sex and body length of the deceased (Buikstra, Ubelaker 1994). Since all the bodies were either mummified and/or dressed, we were only able to collect very basic information on the biological profile of the individuals. Sex estimation either relied on the presence of genitalia or on the X-rays of the pelvis and skull (Ferembach et al. 1979). The state of dentition, skeletal maturation and degenerative changes were considered for the estimation of age-at-death. Total body length was contrasted with calculated body height. Pathological particularities (e.g., caries, fractures) were noted whenever visible. As a limitation, none of the classical anthropological occupational or stress markers (e.g., Cribra orbitalia, periosteal reactions) could be systematically assessed (Grupe et al. 2015: 340-353, 367).

The mummies were searched for any postmortem changes, such as traces of evisceration or embalming. In selected cases, samples for stable isotope (carbon, nitrogen, sulphur) and aDNA analysis were taken at an inconspicuous location. The samples are currently analyzed at the Institutes of Forensic Medicine of the Universities in Bern and Zurich (Switzerland) to test for kinship, diet, weaning and origin of the individuals.

The commingled human remains stored at the attic, which probably represent the bodies translated in 1828 , were also analyzed to determine a minimum number of individuals (see Indra et al. 2020).

Puparia, empty shells from which adult insects had successfully hatched, were collected at several locations at the bodies and within the textiles. Analyses are currently performed at the Institute of Forensic Medicine in Frankfurt/Main (Germany).

Even though it was neither the goal nor did the (logistical and financial) circumstances allow for an extensive conservation, minor conservation measures were conducted during the project, including superficial cleaning of the coffin surfaces and textiles, as well as the fixation of loose drapery. Together with the State Heritage Office and the Parish, it was decided to improve the presentation of some naked bodies, now wrapped in white silk and placed at a height appropriate to the exhibits. Protective measures also included new Tyvek covers for the coffins and acid-free cardboard backboards.

\section{Results}

Coffins

In contrast to other Eastern German burial crypts (Ströbl 2016a; 2017a; Ströbl et al. 2019), there are only wooden coffins in Riesa, mostly made of oak or pinewood. Both single and double layered coffins occur; however, there seems to be a chronological tendency towards double coffins of being reserved to adults during the $17^{\text {th }}$ century 


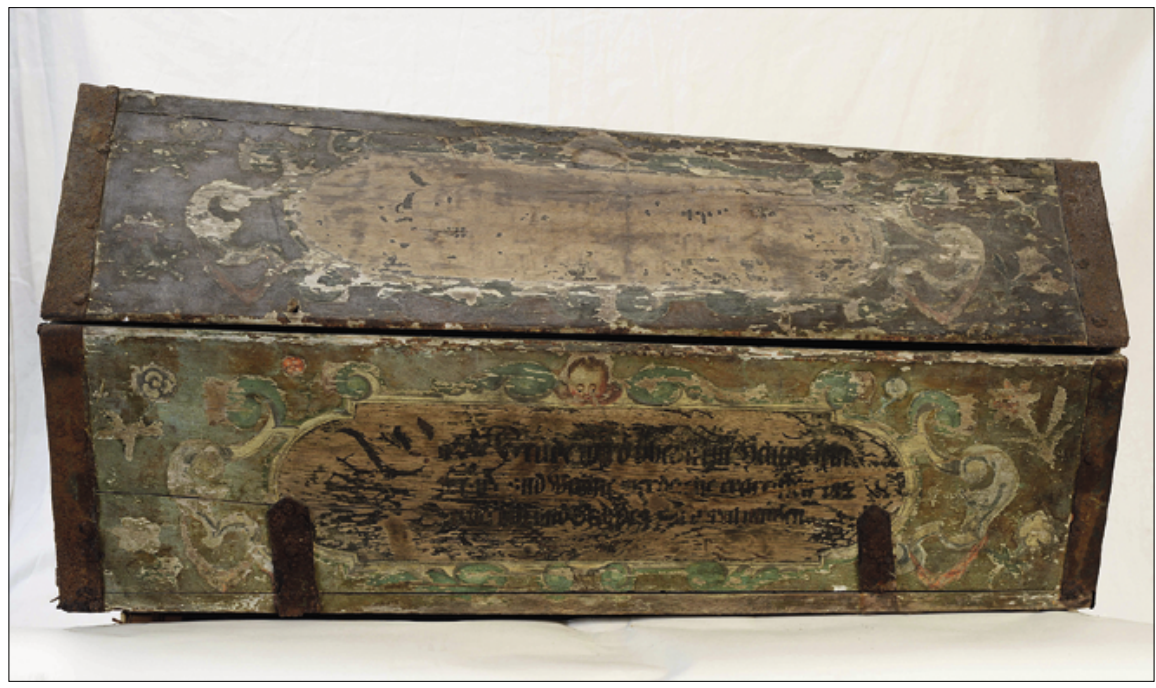

Fig. 5. Painted coffin 4 with iron clasps, biblical quotation (Esa. 35,Io), floral ornaments, and putti, post-I637 (photograph by S. Giersch).

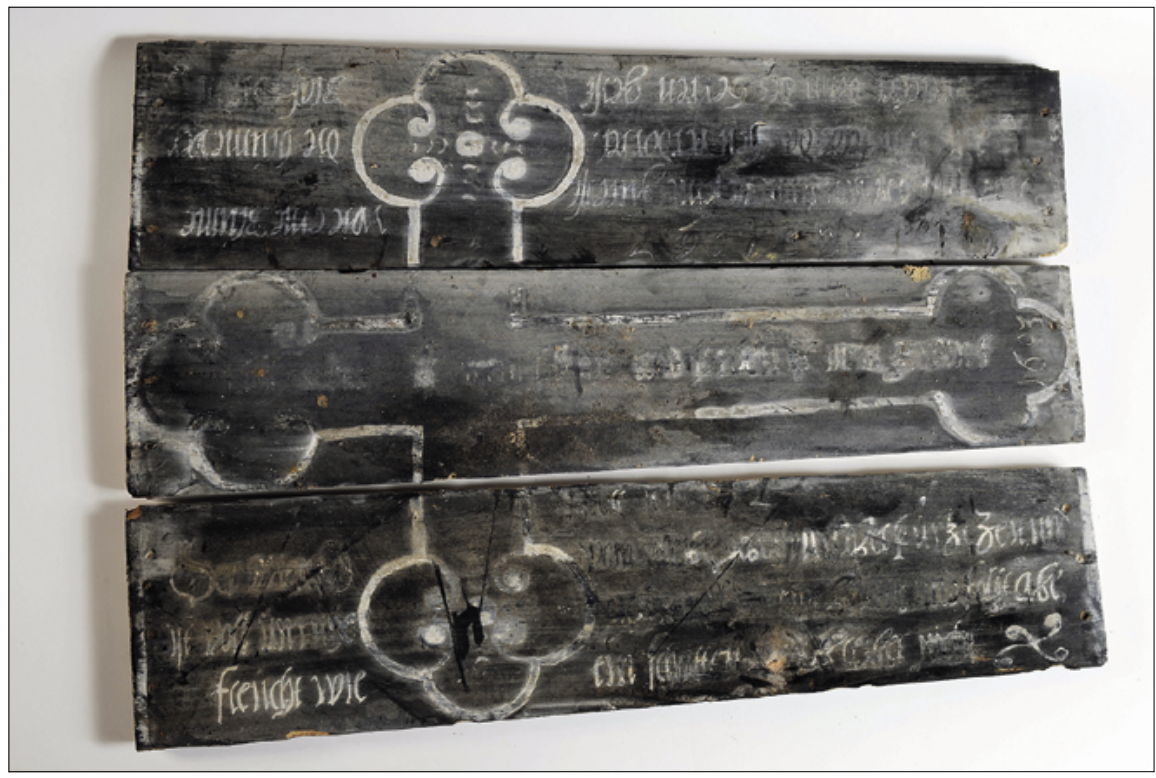

Fig. 6. One of the coffins translated in 1828 , belonging to Ludovica Louisa von Felgenhauer ( $\dagger 1693$ ), with cross and biblical quotations (cross: Phil. I,2I; right side plate: Hiob I4,I-2; left side plate: Esa. 40,6-7) (photograph by S. Giersch). 
(e.g., coffin 10 ), while in the $19^{\text {th }}$ century northern crypt, they appear for both children (e.g., coffin N2) and adults (e.g., coffin N5). In terms of coffin shapes, a range of trapeze-gabled, hexagon-gabled and hip lid coffins could be observed, all with a trapezoid base (Ströbl 20I4). As known from other sites, painted trapeze-gabled coffins are restricted to the $17^{\text {th }}$ century, while hexagon-gabled coffins only appear in the first half of the $18^{\text {th }}$ century. The $17^{\text {th }}$ century coffins follow the standard decoration patterns of their time (Ströbl, Vick 2007; Alterauge et al. 2014; Ströbl, Ströbl 2017; Ströbl et al. 2019): a painted crucifix (or cross) on the lid and biblical inscriptions on the sides, often surrounded by floral ornaments, sometimes crowned with putti (Fig. 5). The white, yellow or golden inscriptions form a remarkable contrast to the blackened surfaces of the coffin (Fig. 6). Iron clasps around the coffin edges are limited to the second half of the $17^{\text {th }}$ century. During the $18^{\text {th }}$ century, more emphasis is put on the visibility of the naked wood, leading thereinafter to profiled, fluted surfaces. As an intermediate step, decorative strips appear on the coffins, imitating coffering (e.g., Fig. 2, children coffins to the right). The climax is reached in mid-1 $9^{\text {th }}$ century coffins with elevated lids and white alloy furnishings (Fig. 5 ).

Coffin furnishings, especially handles, are more common in adult than in subadult coffins, not only to ease the transport, but also due to their representative nature. Until the $19^{\text {th }}$ century, none of the children under the age of 8 years are equipped with coffin handles in Riesa. To protect the dead until the day of judgment, all the coffins were originally sealed, until they were opened in 1828 . The coffins were either sealed with nails or - in few cases - with locks or hooks. The latter theoretically allowed a repeated farewell from the deceased, as did windows in the coffin lid (Ströbl, Vick 201r: 102).

The coffin padding mostly consisted of wood shavings, possibly originating from the coffin fabrication. It served two purposes: to keep the deceased at an elevated position in the coffin, like during eternal sleep, and to absorb body liquids. The padding was covered with linen or silk lining, attached to the coffin's edges. In most cases, the coffins were equipped with cushions, filled with straw, hay or brushwood. Other plants, such as boxwood and yew branches, were part of the coffin furnishing and symbolized as evergreen plants eternal life.

\section{Inscriptions}

The observed coffin inscriptions can be divided into the following categories: biblical quotations, biographical information on the deceased (e.g., name, genealogy, date of birth and death) and folkloric proverbs. All inscriptions are in German and refer to different aspects of death and resurrection. The emphasis on words is typical for Protestant $17^{\text {th }}$ century inhumations, and the coffin decoration and funerary goods were intended to support the written message (Ströbl 2016b: 87). 


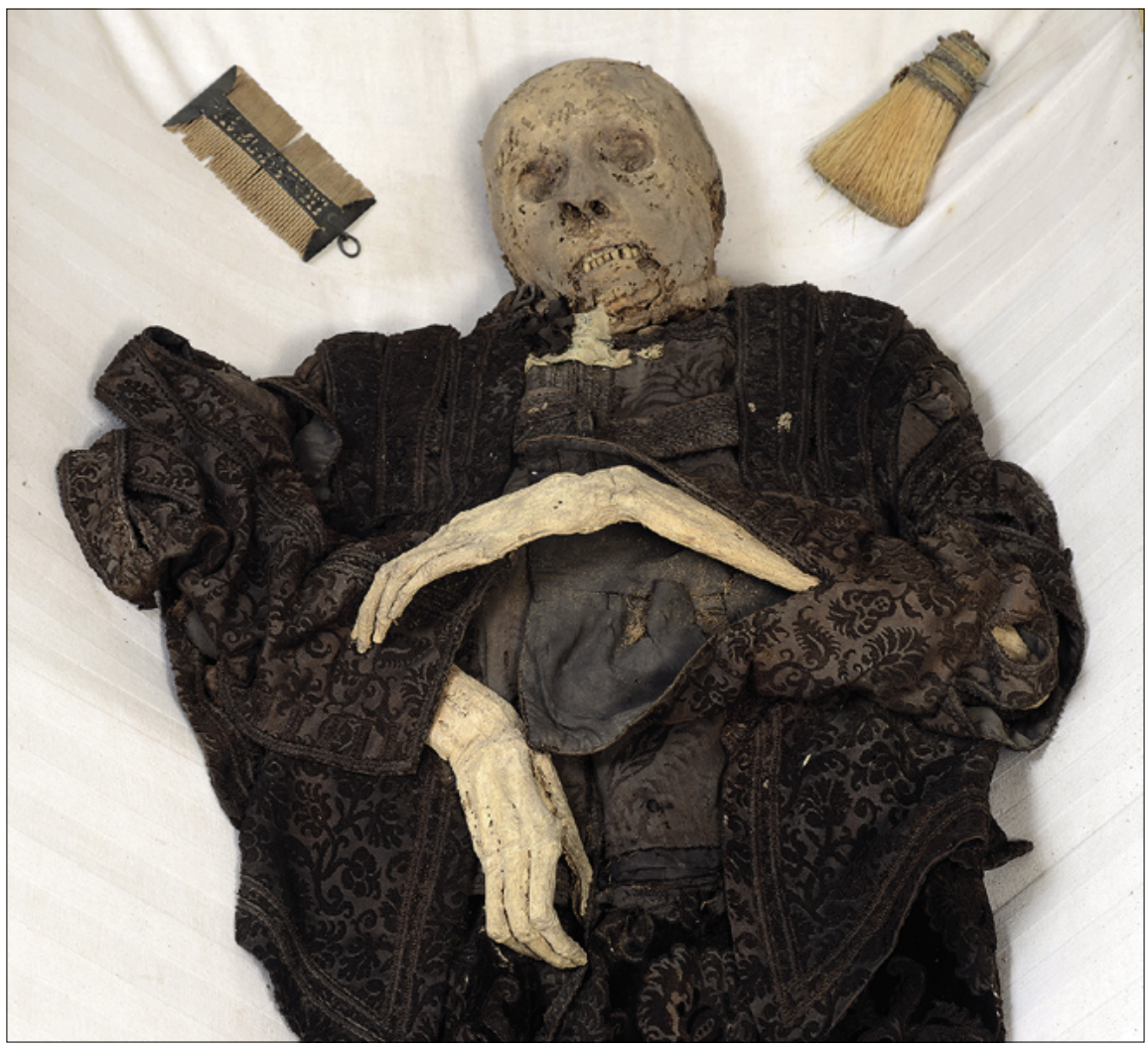

Fig. 7. Coffin $\mathrm{I} 3$ of a female member of the von Felgenhauer family, late $17^{\text {th }}$ century. The white drapery was added in 1978 . Note the presence of a comb and a brush. The individual was buried in adapted clothing, namely a velvet male jerkin (photograph by S. Giersch).

The late $17^{\text {th }}$ century children coffins provide the richest collection in biblical quotations. In times when infant mortality was very high and only about one third of the offspring reached reproductive age, death accompanied every life from the very beginning. However, the inscriptions and funerary provisions reveal that the death of every child hit his parents hard. For example, Christoph Ludwig von Felgenhauer (1650-1707) had 19 children from two wives, of whom only six reached adult age. Parents grief was voiced through the inscriptions on the coffins, for instance with reference to premature death (Hiob I 4,I-2; Sap. 4,7; Esa. 38,13) (Fig. 6). At the same time, the inscriptions allude to the vanity of life (also: Hiob I 4,I-2; Esa. 40,6) and the voidness of human existence (Ps. 30,I). But on the other hand, they provide solace to the bereaved since God offers salvation to the little ones (Mark I0,I4; Mt. I8,I 4) who have pleased him (Sap. 4,IO). Only 
God can provide calmness and peace during eternal sleep (Ps. 4,9). In addition, God redeems the deceased from sin (Joh. I,8; Sap. 4,20) and offers them eternal life. For this reason, death is seen as gain (Phil. I,2I) (Fig. 6).

Despite the uniformity of the quotations, which were probably at least partly taken from Martin Luther's preface to his Begräbnislieder (1542) (Ströbl 2017b), there was also room for individuality. Older children received other quotes than the still- and newborns, e.g. by referring to the years not-to-live (Sap. 4,8-9; Sir. 42,5-7) or to the heavenly reunion with God (Hos. 2,19-20; Ps. 45,10,15-16). Great sorrow expressed through some folkloric proverbs (Today red, tomorrow dead) alluding to the sudden and unexpected death of children.

The few adult coffins with inscriptions, one belonging to Maria Magdalena von Felgenhauer ( $\uparrow_{1676}$ ), show similar inscriptions to those for children (Sap. 4,7; Rom. I 4,8) but put a larger emphasis on belief in God (Joh. 3,16) and a righteous life (Sap. 4,7,I4) as a precondition to reach salvation. Unique to the adult coffins are quotations on the bodily resurrection (Hiob 19,25-27), depicting a physical resurrection with own skin, flesh and eyes. In which way mummification might have facilitated resurrection, is rather a matter for theological discussions.

In contrast to their older counterparts, no inscriptions were directly written on the $19^{\text {th }}$ century coffins. Instead, they have lead inscriptions plates attached to the lids, revealing the identity and rank of the deceased (Fig. 4). Nonetheless, in the northern crypt, these plates also contain religious quotations (Joh. II,25; Matt. 19,14; Ps. 4,9; Jes. I,6; Jes. 49,16), revealing the faith in God and hope of resurrection was hardly on the wane.

\section{Grave goods}

We define grave goods as objects that were unambiguously deposited with the deceased, while elements of clothing (hooks and eyes, pins, buckles) are to be treated together with the corresponding attire. We distinguish between profane and symbolic or religious burial goods, even though ambiguity might be inherent in all objects given to the deceased.

Profane utensils used for the cleaning, shaving and general preparation of the body for the funeral are the most common finds from the crypt, even though we cannot calculate their frequency due to their recovery as stray finds and not surely attributable objects (Fig. 7). Combs, washing brushes (previously interpreted as razor brushes or aspergillum), sponges and washing pans might have touched the dead and were therefore considered baneful and impure for further use (Ströbl, Vick 2009: 320). For this reason, these objects had to be removed from the world of the living, possibly also out of fear of the revenant dead (Melisch 2015: II4), and were placed into the deceased's coffin. Jewellery (ring, earring, necklaces, and amulets) was only preserved 


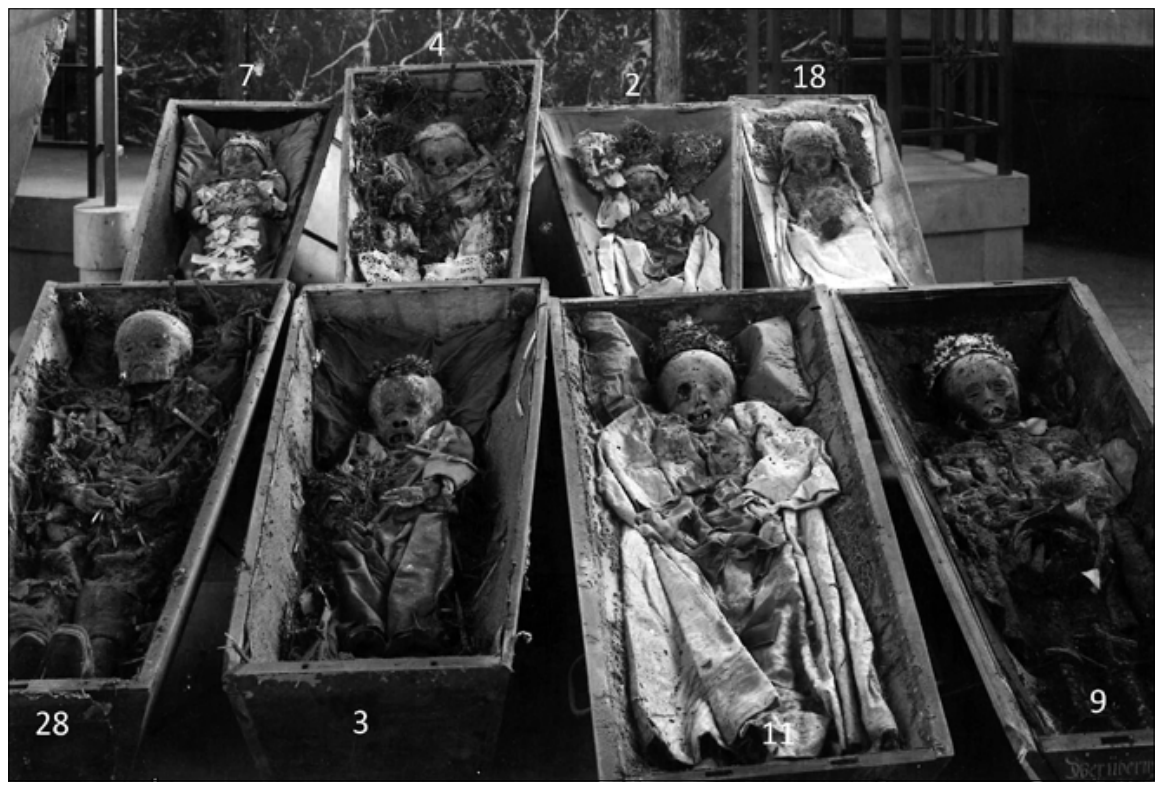

Fig. 8. Photograph of some children coffins in front of the altar, taken in 1923 on order of Franz Xaver Hynek (I879-I952) (Credit: City Museum Riesa). The funeral wreaths are still in place. Note also the funeral crosses and flowers arrangements in some coffins, e.g. coffin 4 , coffin 28 . Coffin assignment by the authors.

in exceptional cases or as stray finds due to previous lootings but was probably more frequent than we know today (see Steeger 2003). From the side chambers, there are for instance a golden ceremonial chain and a signet ring preserved.

Through historical records, we know of the presence of additional grave goods, which are no longer available for analysis. Two individuals were buried with prayer books and inlaid devotional images that are typical grave goods of the Protestant elite (Kenzler 20II: 25). Clay eggs were found in one coffin, symbolizing life and resurrection. Unique are so far playing cards that were found in the coffin of Magdalena Ficker, née von Felgenhauer (1606-1674) (Voigtländer, Hennig I892).

While the above-mentioned grave goods were exclusively given to adults, the children burials contain plenty of religious or symbolic objects. Funeral wreaths (or crowns) belonged to the grave goods denoting status, given to unmarried individuals and symbolizing a bridal crown as well as the innocence and virginity of the deceased. A photograph from 1923 shows the funeral wreaths from Riesa still in their original position, deposited on the heads and on the postcranium of both girls and boys (Fig. 8). During her investigation of the remaining funeral wreaths at the City Museum of Riesa, Lippok was able to distinguish different types and shapes 
of wreaths, dating from the $17^{\text {th }}$ till $19^{\text {th }}$ century, which show strong similarities to the funeral wreaths from Dresden (Lippok 2016) and Freiberg (Schubert 2014: 225). The wreaths are made of leonic wires being silver-plated or gold-plated copper wires and threads, which were formed into floral ornaments and accompanied by beads, silk decoration elements, paper flowers and real cloves.

The $17^{\text {th }}$ century children inhumations were also equipped with funeral crosses, which were once carrying a three-dimensional Jesus figurine (Fig. 8). The crosses are black with golden stars at the end of the arms and placed in the left elbow of the deceased (Fig. 9). In Riesa, those funeral crosses were only given to children above the age of three months and are often correlated to funeral wreaths whereas elsewhere, they occur in adult burials, too (e.g. Freiberg; Schubert 2014: 227).

Other typical Saxon children grave goods were wreaths or bunches made of splinter wood and covered in cloves thread onto fine wires (Fig. 9, I0). The cloves appear in the form of flowerbuds or mother cloves, both sometimes gilded (Hofmann 2012: 5I). The cultivation of cloves was restricted to the Spice Islands (today: Moluccas in eastern Indonesia) until the ${ }_{1} 8^{\text {th }}$ century, and their export was strictly controlled by the Dutch. Therefore, together with nutmeg and piment, cloves belonged the most valuable plants of their time and were a sign for social distinction. Besides, cloves have also a symbolic meaning representing the nails used for the crucifixion of Christ (Ströbl, Ströbl 2020: 253).

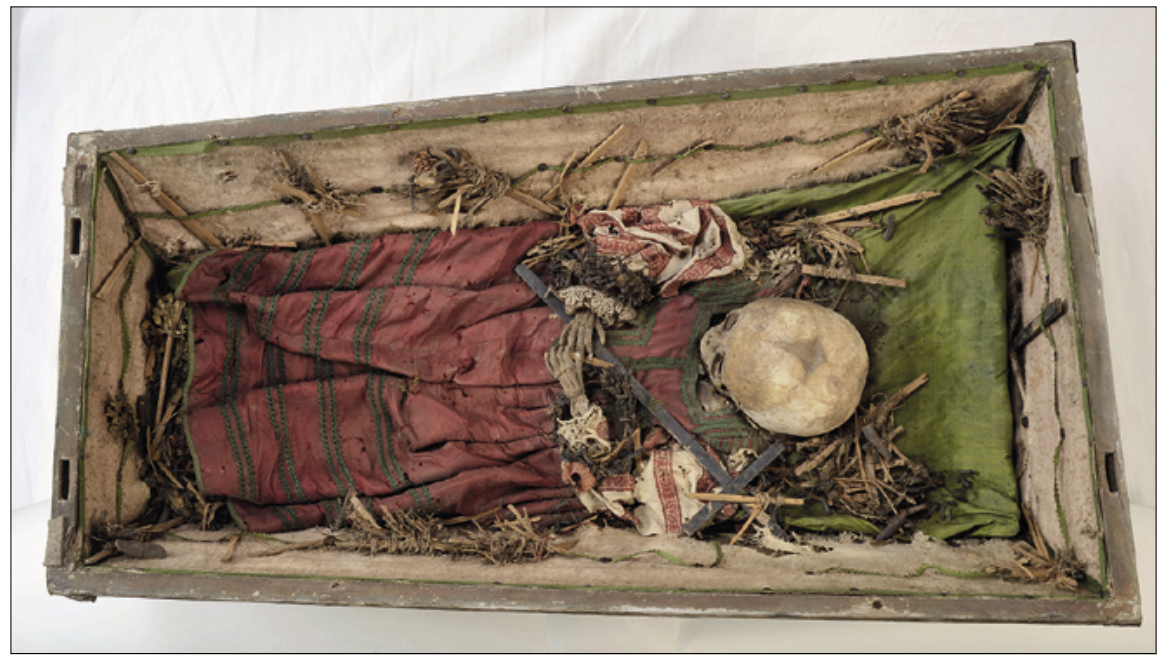

Fig. 9. Coffin 4 of an infant in a red silk taffeta bodice and skirt and a white blouse with red-white braids. Shoes and stockings are not visible, a bonnet and blanket were removed in 1923. The funeral cross and the clove-covered wreaths around the wrists are still present, as are the bunches of splinter wood, flowers, cloves, and boxwood. Dating: post-I637 (photograph by S. Giersch). 


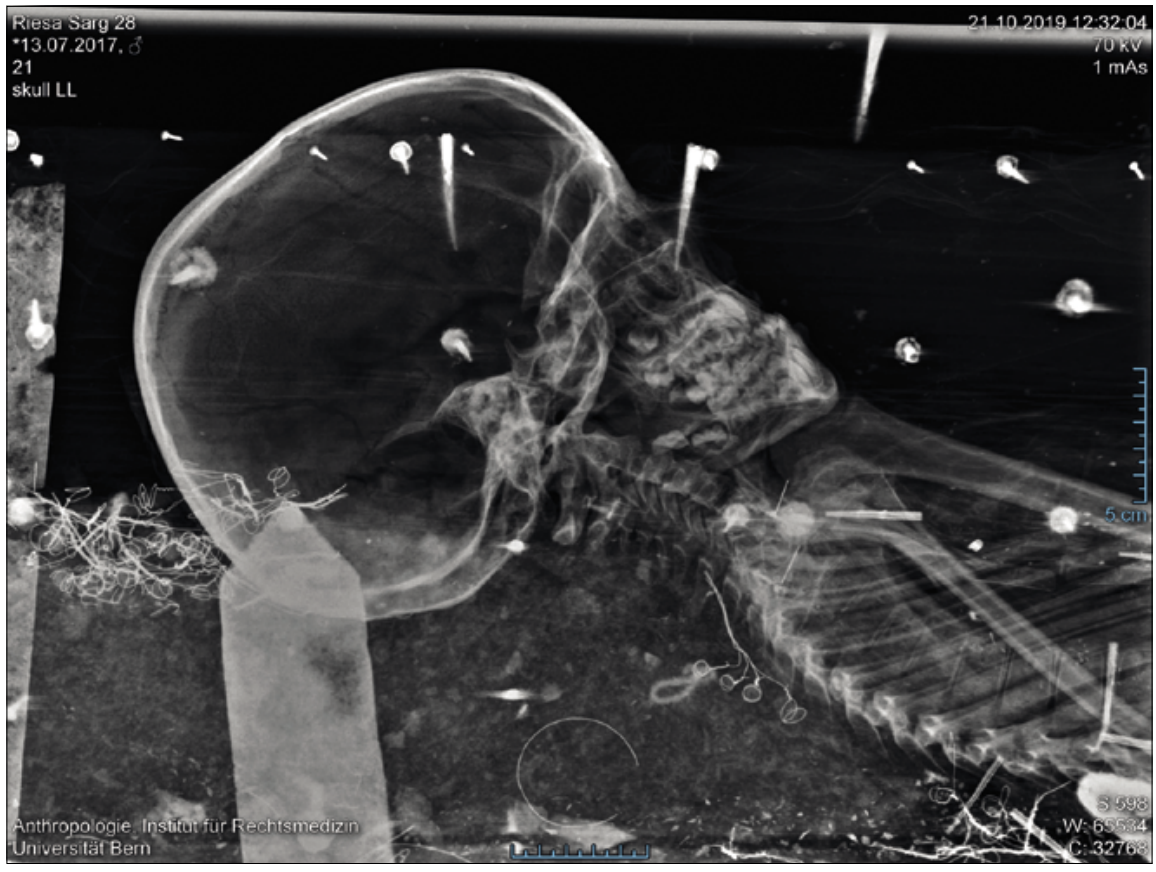

Fig. 10. Lateral X-ray of coffin 28 , containing the inhumation of a boy of $5-7$ years, late $17^{\text {th }}$ century. Due to the two-dimensional projection, the metallic structures of the coffin (e.g. iron clasps, coffin nails) overlap the image of the deceased. Thread and drilled cloves are visible above the head and next to the chest. Courtesy of the Institute of Forensic Medicine, University of Bern.

To the coffins' embellishment also contributed bunches of splinter wood and artificial flowers, feathers or gilded laurel leaves which are a sign of the elaborate handicraft of the $17^{\text {th }}$ century (see Steeger 2003).

So far, it seems that the $17^{\text {th }}$ century inhumations were equipped with objects of higher value, quality and quantity than during later times. On the one hand, this practice mirrors the contemporary funerary customs of the nobility and bourgeoisie in Saxony (Hofmann 2009; 2010; 2012; Ströbl et al. 2019), but also in neighboring Poland (Majorek, Grupa 2016), on the other hand, it highlights the achievements of the von Felgenhauer family.

While we need to keep in mind that the sample is biased towards $17^{\text {th }}$ century children burials in terms of quantity and preservation, no funeral wreaths or flower bunches are reported from the children coffins of the Hanisch/von Odeleben family. So-called luxury decrees prohibited in the $18^{\text {th }}$ century the excess luxury and splendor of funerals, leading to the use of different techniques and materials in the fabrication of funeral wreaths (Lippok 2013: 197-198). We suggest that the 
floral wreaths made of flowers, laurel and moss from the mid-1 $9^{\text {th }}$ century children burials in the northern crypt are to be considered in this context.

\section{Clothing}

Burial clothes may be seen as a representation of the deceased's social identity and dressers' perception of death and the deceased. Within this framework, it was not only significant which kind of clothing was used to wrap the deceased, but also from what kind of materials they were made. Due to their excellent preservation, the garments from Riesa are a valuable source for research in early modern costume and art history as well as textile craft. Even though clothing is not preserved for all the inhumations or fragments can no longer be attributed to specific individuals, they add nicely to the textile corpus from Dresden Frauenkirche and Sophienkirche (Hofmann 2009). In Riesa, both clothes worn during lifetime and burial gowns occur, even though the differentiation is not always simple. We may differentiate between the following categories of clothing (adapted from Grömer, Ullermann 2020):

- Full wearable attire with outer- and underclothing, bonnet, stockings and shoes (e.g., coffin 4) (Fig. 9);

- Re-worked, adapted clothing, meaning private clothes, not necessarily the personal ones, draped with pins or open back (e.g., coffin I3) (Fig. 7);

- Burial gowns which were exclusively made for the funeral, often simple shirts or dresses without haberdasheries, often only applied to the body (not dressed) (e.g., coffin 2) (Fig. II);

- Wraparound garments for still- and newborns (coffin 19, 20).

So far, we were not able to detect any chronological changes in the preferment of wearable or funeral attire. If anything, children seem to be buried more often in burial gowns than adults, especially the very young ones ( $<3$ months), if they were not buried in wraparounds.

Different material of the clothing could be determined: silk, satin, taffeta, and velvet dominate the outer clothing, while wool is quite uncommon, except in jackets of coffin 27 and 28. Linen is seen in undergarments, such as shirts. In general, as often seen in crypt burials, the preservation of animal protein fibres is much better than of plant fibres. Being the most expensive fabric at the time, dressing the dead in silk defined univocally that the deceased was a member of the elite. Ornamenting motifs of the woven fabrics took the form of geometric or floral shapes. Laces, ribbons, and bows were used for decoration of the clothes, but were also regularly found tied around the wrists of the deceased. Haberdashery included hooks and eyes, spherical and round coated buttons, iron hooks, and shoe buckles.

Besides, not only the clothing was made of silk but sometimes also the coffin lining. In contrary to textiles from archaeological context, the observed textiles 


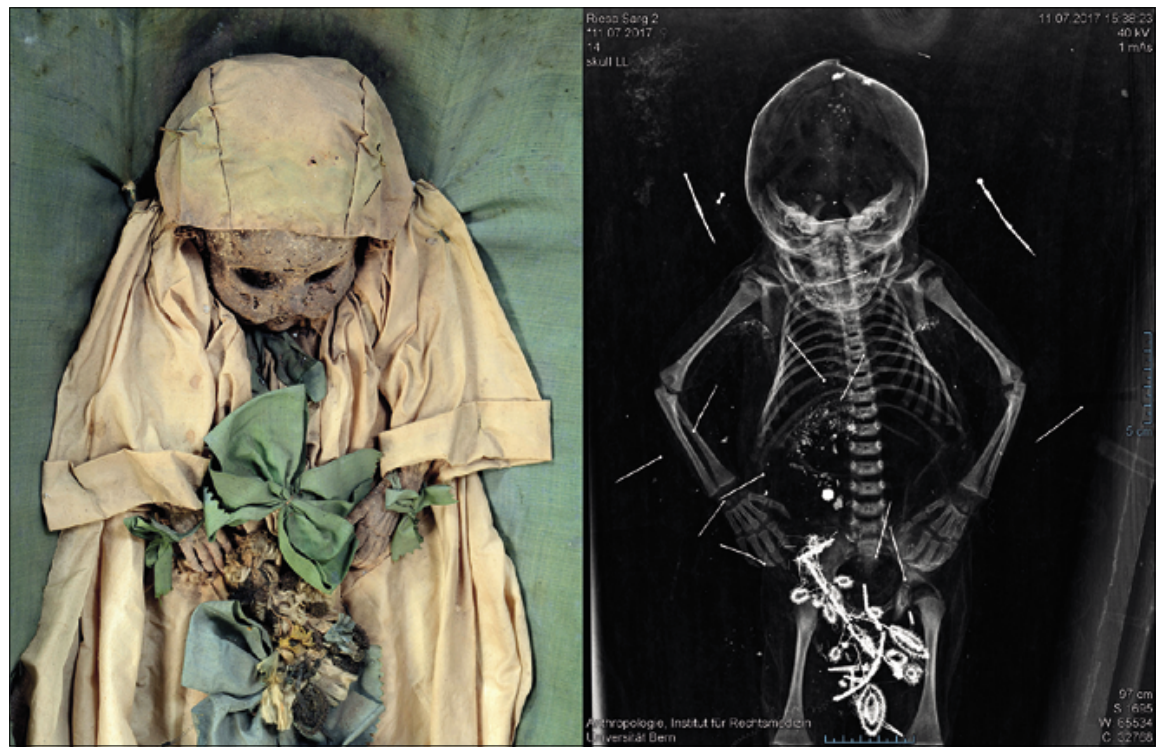

Fig. 11. Photograph and anteroposterior $\mathrm{x}$-ray of coffin 2 , infant of $\mathrm{o}-3$ months. The individual was dressed in a beige silk taffeta burial gown with green bows, which was pinned in shape. A flower bouquet from leonic wires and silk flowers was placed on the lap. The metallic components are revealed by the x-ray (photograph by S. Giersch; X-ray: courtesy of the Institute of Forensic Medicine, University of Bern).

appear in yellow, red, green, black, brown, and light blue shades of color and have mostly kept their luminance and pliability. The child burials are rather associated with bright and vivid colors highlighting the innocence of the deceased, while black clothing is restricted to adult inhumations.

Identification and health

From the genealogies and death registers, we have a pretty good understanding of who was buried in the crypts (Thomas 193I), even though little inconsistencies in name spellings or date of birth and death might occur in-between sources. Members of the families von Felgenhauer, von Grünrodt, von Gersdorff, and Hanisch/von Odeleben were entombed in the crypt below the altar, while only members of the von Welck family were interred in the northern crypt. It is noteworthy that not only Felgenhauers residential in Hirschstein Castle were buried in the crypt, but that daughters who had married into other families and moved away were sometimes transported to Riesa in order to be interred alongside their relatives. 
Thanks to the $\mathrm{x}$-rays, the age and sex of all the mummified individuals from the crypts could be determined. The age ranges from still- and newborn infants (Fig. II) to older children and from young adults of both sexes to middle-aged men and elderly women. The morphological age-at-death estimations were compared to the historical data of the deceased to verify the identifications which are based on the official documentation from $\mathrm{I} 828$. As a result, all identifications adapted from the coffin inscriptions or inscription plates are plausible, and as additional evidence, the style and cut of the clothing can be taken as further affirmative chronological element. However, the identifications are less reliable when it comes to the inhumations without inscriptions. Here, the aDNA analysis can provide clues by revealing kinship relations between identified and unknown individuals, as will the forensic entomological analysis on the season at death.

Information on the health of the entombed individuals offer valuable insights into the living conditions of the lesser nobility in Saxony. As limitation, the overlap of radiodense structures hampered a systematical paleopathological approach, so that we can only list single conditions, such as caries, antemortem tooth loss, healed fractures, and spinal degenerative changes. Two isolated fontanelle plates were recovered as stray finds and attest the application of medicinal practices by which an ulcer was artificially induced and kept open in sense of the humoral-pathological ideas (Häck, Nerlich 2016: 297-303).

Sometimes, the death register offers additional information on the cause of death, e.g. death in childbed, child variola (probably chickenpox), edema, hemorrhage, diphteria and dysentery.

\section{Mummification}

During the project, 29 mummies could be investigated by means of visual inspection and radiography. They are of leathery appearance with dried skin and soft tissue. Except in one individual (coffin $\mathrm{x}$ ), no incisions or residues of embalming fluids could be observed, which suggests that we are predominantly dealing with spontaneous mummies created unintentionally due to the environmental conditions. The crypts are well ventilated with gentle variation in temperature and relatively low humidity, as shown by our current hygrometric climate control. As reported in 1828 , the coffins which were located close to the ventilation openings showed the best preservation of the body as of the wood. The coffins' furnishing with wood shavings might have enhanced the mummification process by absorbing the body fluids and emitting tannic acids. It was also favorable that the entombment usually took place within four days after death, if the funeral was not delayed due to a transport from far away or other external circumstances (e.g., gathering of the family). 
There has been a lively debate for years if there is a tradition of intentional mummification in Christian Middle Europe (Schmitz-Esser 2014: 298-299). Especially from the early modern period, there are thousands of dry mummies of the social elite preserved in family- and church vaults (Behre 1956; Jungklaus, Vick 20II). Nonetheless, the physical completeness of the body was an accepted, yet unintended, side effect of crypt burial even though the phenomenon evoked the curiosity of the contemporaries and descendants. We might believe that it was not only the ambition to possess a representative family vault, that has inspired the barons von Welck for the foundation of the northern crypt, but also their knowledge of the conservatory effects of the place.

\section{Occupation}

Despite the rich archival records, it is to date still very difficult to determine the occupation time of the crypt below the altar. That is because we do not know the exact construction date of the crypt, even though we might assume that it accompanied the erection of the choir. Whether this happened already in 1622 , when Christoph von Felgenhauer (II) purchased Riesa manor, is not documented. This is quite surprising since we know of his other endowments, e.g. the organ. The oldest inhumation in the crypt is that of an infant of about 3-9 months who was entombed in a painted coffin with iron clasps (Fig. 5). A blanket found in the coffin is embroidered with the initials "REvG" and the year I637, but we did not find a corresponding death in the church register. Therefore, we can neither exclude that this infant was buried in the crypt already in 1637 , nor that the blanket was given to it at a later date. According to the absence of year-dated coffins and corresponding entries in the death register, none of the children of the first and second marriage of Christoph von Felgenhauer (III) (I608-1679) seem to have been buried in the crypt. It is possible that the siblings Christoph von Felgenhauer (III) and Magdalena Ficker (1606-1674) were the first von Felgenhauer to be interred in the crypt, namely in the antecedent side chambers with their respective spouses (Voigtländer, Hennig I892).

The death register is also not very precise about the exact location of the interments and is therefore not providing any additional clues: until 1679 , there has been a standard formula, wishing the deceased gentle peace and a joyful resurrection for eternal life in its resting chamber. Afterwards, the entries are more precise, stating the entombment in the Felgenhauer, aristocratic, or ancestral sepulture. From 1755 onwards, the crypt was referred to as the manorial crypt, a term that was later also used for the northern crypt of the family von Welck.

The last inhumations before 1828 were members of the middle-class and later ennobled family Hanisch or von Odeleben. However, in 1923 , a $3 \mathrm{I}^{\text {st }}$ coffin 
is reported in the crypt which obviously was entombed there after the official documentation in I828. It is believed that it is the body of Ernst Otto Innocenz Freiherr von Odeleben (1777-1833), a cartographer in Napoleon's services, who was transported by the von Welck brothers after his death in Dresden to the crypt in Riesa (Brunner 2007). An oval incision, the cut of the sternum and stitching on the abdomen revealed that the corpse had been eviscerated. However, the morphological analysis has raised doubts on the identity of the corpse, and no such incident is reported in the diaries of Curt Robert Freiherr von Welck (pers. comm. Josef Matzerath, Dresden 2018), nor is there any entry in the death register. Additional scientific analyses are currently performed to reveal the identity of the deceased.

The northern crypt was founded in 1856 following the death of Anna Editha Freifrau von Welck (I828-1856), accompanied by the exhumation of her daughter Sara (I855-1856). The crypt was used until 1869 , sheltering in the meanwhile three generations of the barons von Welck.

\section{Conclusion}

The documentation of the burial crypts in the cloister church of Riesa allowed high-quality recovery of extensive burial data, including interments where coffins, clothing, and mummified remains were not only encountered, but thoroughly recorded and analyzed (Alterauge, Hofmann 2019). The prominent position of the owners of Riesa manor became evident in the elaborate design and quality of the coffins, furnishings, grave goods and clothing. The inhumations show changing influences of style, fashion and time on a local and regional level, particularly evident in the children burials. We hope that further bioarchaeological research will help to elucidate the identity of the so far unknown individuals, which again will add reliable information on the funerary customs.

Alongside with the ongoing scientific analyses, this study has the potential to give a fuller understanding of the identity and mind-sets of early modern ennobled families.

\section{Acknowledgement}

Special thanks go to all the people who have contributed to this research by assisting during the documentation on site (Steffen Giersch, Michael Herold, Sebastian Herold, Lara Indra, Birgit Seeländer, Eva Jacqueline Wojas, Andreas Wolf) as well as in the following comparative analysis (Manfred Dietrich, Manfred Jope, Annegret Michel, Maritta Prätzel, Volker Thomas). 


\section{Bibliography}

Alterauge A., Hofmann C. (2019), Mumien in der Klosterkirche von Riesa. Die Grüfte der Familien von Felgenhauer und von Welck, "Sächsische Heimatblätter", 65 (3), p. 252-257.

Alterauge A., Bodenstein J., Streitz C., Friske M., Rosendahl W. (2014), Zwei Erbbegräbnisse des I8. Jahrhunderts in der Westhalle der St. Katharinenkirche zu Salzwedel. Archäologische und anthropologische Untersuchungsergebnisse zum Totenbrauchtum in der Altmark, [in:] K. Simitopoulou, B. Kaufmann, K. Zafeiris, T. Theodorou, C. Papageorgopoulou (ed.), Anthropological Pathways. Festschrift for Professor N.I. Xirotiris, Mystis, Komotini, p. 249-267.

BehreA. (1956), Natürliche Mumifizierungen, "Naturwissenschaftliche Rundschau", 5, p. 175-180.

Brunner H. (2007), Odeleben (bis I79o Hanisch), Ernst Otto Innocenz Freiherr von, [in:] Sächsische Biographie, Institut für Sächsische Geschichte und Volkskunde e.V., http://www.isgv.de/saebi/ (access 24 X 2018).

Buikstra J.E., Ubelaker D.H. (1994), Standards for Data Collection from Human Skeletal Remains, Arkansas Archeological Survey, Fayetteville (Arkansas Archeological Survey Research Series, 44).

Dannenberg L.-A., Westphalen T. (2019), Kloster Riesa, "Sächsische Heimatblätter”, 65 (3), p. 229-234.

Donath M. (2019), Die Familie von Felgenhauer in Riesa und Hirschstein, "Sächsische Heimatblätter", 65 (3), p. 243-246.

Ender P., Ender W., Huth M., Kavacs G., Strobel M. (2007), Stadt und Kloster Riesa. Archäologie und frühe Geschichte, Dresden Landesamt für Archäologie, Dresden (Archaeonaut, 7).

von Feilitzsch H.E.F. (I896), Zur Familiengeschichte des Deutschen, insbesondere des Meissnischen Adels von 1570 bis ca. I820, Großenhain-Leipzig.

Ferembach D., Schwidetzky I., Stloukal, M. (1979), Empfehlungen für die Alters- und Geschlechtsdiagnose am Skelett, "Homo", 30, p. I-32.

Grömer K., Ullermann M. (2020), Funktionstechnische Analyse von neuzeitlichen Kleidungsstücken aus der Michaelergruft, Wien I, [in:] Th. Kühtreiber, R. Risy, G. Scharrer-Liska, C. Theune (ed.), Leben mit dem Tod. Der Umgang mit Sterblichkeit in Mittelalter und Neuzeit, Österreichische Gesellschaft für Mittelalterarchäologie, Wien (Beiträge zur Mittelalterarchäologie in Österreich, 35), p. 227-236.

Grupe G., Harbeck M., McGlynn G.C. (2015), Prähistorische Anthropologie, Springer, Berlin-Heidelberg, https://doi.org/I0.1007/978-3-642-55275-5

Gurlitt C. (19I4), Beschreibende Darstellung der älteren Bau-und Kunstdenkmäler des Königreichs Sachsen, vol. xxxviII, Die Städte Großenhain, Radeburg und Riesa, Meinhold, Dresden.

Häck B., Nerlich A.G. (20I6), Bleiplatten und Fontanellenbleche in mittelalterlichen und neuzeitlichen Gräbern als medizinische Behandlungsform. Vorberichtzu einer archäologischpaläopathologischen Studie, "Vorträge des Niederbayerischen Archäologentages", 34, p. 267-320.

Herrmann B., Grupe G., Hummel S., Piepenbrink H., Schutkowski H. (1990), Prähistorische Anthropologie. Leitfaden der Feld- und Labormethoden, Springer, Berlin-Heidelberg-New York, https://doi.org/Io.1007/978-3-642-61514-6

Hofmann C. (2009), Der Tod geht uns nichts an. Dokumentation und Restaurierung von Totenkleidung aus dem I6. bis I9. Jahrhundert, "VDR - Beiträge zur Erhaltung von Kunst- und Kulturgut", 2, p. 8o-87. 
Hofmann C. (2010), Dokumentation und Restaurierung von Totenkleidung aus dem I6. bis I9. Jahrhundert, [in:] K. Ellwanger, H. Helmhold, T. Helmers, B. Schrödl (ed.), Das "letzte Hemd". Zur Konstruktion von Tod und Geschlecht in der materiellen und visuellen Kultur, Transcript-Verl., Bielefeld, p. 25-40.

Hofmann C. (20I2), Ihr Name war Sophia - Geschichte eines Grabfundes, "Dresdner Geschichtsbuch", 17, p. 39-55.

Indra L., Alterauge A., Lösch S. (2020), A Probable Case of Diffuse Idiopathic Skeletal Hyperostosis from an Early Modern Crypt in Eastern Germany, "International Journal of Osteoarchaeology" 30 (6), 2020, 903-908, https://doi.org/IO.I002/oa.2913

Jungklaus B., Vick D. (20II), Mumienfunde in neuzeitlichen Grüften in Berlin, Brandenburg und Niedersachsen, [in:] W. Neumann (ed.), Geschichte und Tradition der Mumifizierung in Europa. Beiträge zu einer Tagung im Museum für Sepulkralkultur 20Io, Arbeitsgemeinschaft Friedhof und Denkmal, Kassel, p. 65-78.

Kenzler H. (20II), Totenbrauch und Reformation. Wandel und Kontinuität, "Mitteilungen der Deutschen Gesellschaft für Archäologie des Mittelalters und der Neuzeit", 23, p. 9-34.

Lippok J. (2013), Neuzeitliche Totenkronen in Deutschland. Untersuchungen zum Erkenntnispotenzial von Materialanalysen unter besonderer Berücksichtigung von Datierungsfragen, "Prähistorische Zeitschrift", 88 (I-2), p. I80-207, https://doi.org/IO.1515/pz-2013-0006

Lippok J. (2016), Totenkronen aus Dresden. Vergleich von konstruktiven Merkmalen, Typologie und Funktion in der neuzeitlichen Sepulkralkultur anhand der Funde aus den Grabungen DD-IS (Frauenkirchhof) und Sophienkirche 1996, "Arbeits- und Forschungsberichte der sächsischen Denkmalpflege”, 2013/20I4 (55/56), p. 219-247.

Lippok J. (2019), Die Totenkronen aus der Gruft der Klosterkirche Riesa (unpublished manuscript, Stadtmuseum Riesa, Berlin).

Majorek M., Grupa D. (2016), Child Burial Wreaths in Early Modern Royal Prussia, [in:] J. Kodzik, W. Zientara (ed.), Hybride Identitäten in den preußisch-polnischen Stadtkulturen der Aufklärung. Studien zur Aufklärungsdiffusion zwischen Stadt und Land, zur Identitätsbildung und zum Kulturaustausch in regionalen und internationalen Kommunikationsnetzwerken, lumière, Bremen, p. 163-172.

Melisch C.M. (2015), Faith and Religious Practice: Sepulchral Culture in Berlin/Cölln (Germany) from the Middle Ages to the Baroque Era, "The Mediaeval Journal", 5 (I), p. I07-I28, https://doi.org/IO.I484/J.TMJ.5.107365

Schmitz-Esser R. (20I4), Der Leichnam im Mittelalter: Einbalsamierung, Verbrennung und die kulturelle Konstruktion des toten Körpers, Thorbecke, Ostfildern (Mittelalter-Forschungen, 48).

Schubert M. (20I4), Barocker Totenbrauch und die Überreste einer Kapelle. Die Ausgrabungen auf dem Grünen Friedhof des Freiberger Doms, "Arbeits- und Forschungsberichte zur sächsischen Bodendenkmalpflege. Beiheft", 27, p. 346-354.

Steeger W. (2003), Zum Wandel der Begräbnisform vom Frühmittelalter bis zum I7. Jahrhundert am Beispiel archäologischer Funde in Bad Windsheim, [in:] A. Thurnwald (ed.), Trauer und Hoffnung. Sterbebräuche, Totengedenken und Auferstehungsglauben in evangelischen Gemeinden, Imhof, Bad Windsheim (Schriften und Kataloge des Fränkischen Freilandmuseums, 4I), p. II-39.

Ströbl A. (2009), Mumien aus Riesa im Museum für Sepulkralkultur, "Friedhof und Denkmal. Zeitschrift für Sepulkralkultur", 54 (5), p. 6-9. 
Ströbl A. (20I4), Entwicklung des Holzsarges von der Hochrenaissance bis zum Historismus im nördlichen und mittleren Deutschland, Fachverlag des Deutschen Bestattungsgewerbes, Düsseldorf (Kasseler Studien zur Sepulkralkultur, 20).

Ströbl A. (2016a), Die Särge der besseren Gesellschaft. Das Inventar der Gruft, [in:] J. Haspel (ed.), Parochialkirche in Berlin. Sakralbau, Kirchhof, Gruft, Michael Imhof Verlag, Petersberg (Beiträge zur Denkmalpflege in Berlin, 44), p. 170-177.

Ströbl A. (20I6b), Adressat Gott? Sargschmuck und -ornamente der frühen Neuzeit, "Archäologie in Niedersachsen", I9, p. 87-9I.

Ströbl A. (20I7a), Sarg und Grabmal - Wechselspiele zwischen Repräsentation und Verbüllung, "Ethnoscripts - Zeitschrift für aktuelle ethnologische Studien", I9 (I), p. 13-36.

Ströbl A. (20I7b), Der Sarg als unsers Herrn Christi Schoß. Luthers Begräbnisgesänge in Sarg-und Gruftinschriften, "Friedhof und Denkmal. Zeitschrift für Sepulkralkultur", 62 (3), p. 24-26.

Ströbl R., Ströbl A. (2017), "Ich habe den Lauf vollendet" - die Särge aus der Bülker Grabkapelle in Dänischenhagen, "Jahrbuch Heimatgemeinschaft Eckernförde e.V.", 75, p. 25I-262.

Ströbl R., Ströbl A. (2020), Mit Näglein besteckt ... Fürsorge über den Tod hinaus, [in:] Th. Kühtreiber, R. Risy, G. Scharrer-Liska, C. Theune (ed.), Leben mit dem Tod. Der Umgang mit Sterblichkeit in Mittelalter und Neuzeit, Österreichische Gesellschaft für Mittelalterarchäologie, Wien (Beiträge zur Mittelalterarchäologie in Österreich, 35), p. 250-258.

Ströbl A., Vick D. (2007), Die Bestattungen in der Äbtissinengruft im Kloster Lüne, "Mitteilungen der Deutschen Gesellschaft für Archäologie des Mittelalters und der Neuzeit", I8, p. 45-55.

Ströbl A., Vick D. (2009), Hopfenbett und Hexenkraut. Oder: Wie christlich ist Aberglaube?, [in:] J. Callmer, R. Struwe (ed.), Glaube - Aberglaube - Tod. Vom Umgang mit dem Tod von der Frühgeschichte bis zur Neuzeit, EAZ, Berlin (Ethnographisch-Archäologische Zeitschrift, 50), p. 3II-326.

Ströbl A., Vick D. (20II), "Mag der Körper doch im Grabe ruhn, für die Seele gibt es keine Gruft". Neuzeitliches Bestattungsbrauchtum im Spiegel protestantischer Gruftanlagen, "Mitteilungen der Deutschen Gesellschaft für Archäologie des Mittelalters und der Neuzeit", 23, p. 97-IO4.

Ströbl R., Ströbl A., Vick D. (2019), “...und keine Qual rühret sie an”? - Rettungsmaßnahmen in der Grablege derer zu Bünau in Burkhardswalde bei Pirna, "Denkmalpflege in Sachsen. Mitteilungen des Landesamtes für Denkmalpflege Sachsen”, 20I8, p. 44-50.

Thomas J. (1928), Mitteilungen aus dem Jahre I828 über die Gruft der Riesaer Klosterkirche, "Unsere Heimat. Blätter zur Pflege der Heimatliebe, der Heimatforschung und des Heimatschutzes", I (24).

Thomas J. (1931), Aus der Familiengeschichte der ehemaligen Adelsgeschlechter auf Riesa. Unter Verwendung von Kirchenbuchauszügen zusammengestellt, "Unsere Heimat. Blätter zur Pflege der Heimatliebe, der Heimatforschung und des Heimatschutzes", 4 (I5).

von Uechtritz A.W.B. (1792), Diplomatische Nachrichten adelicher Familien als derer $v$. Brandenstein, [...], v. Felgenhauer, [...] betreffend, Leipzig.

Voigtländer T. (I86I), Die Leichen im Erbbegräbnis des Schlosses zu Riesa, "Sachsengrün. Culturgeschichtliche Zeitschrift aus sämmtlichen Landen Sächsischen Stammes”, 2 (2), p. I3-I5.

Voigtländer J., Hennig K. (I892), Die Leichen im Erbbegräbniß des Schlosses zu Riesa. Aufgeschrieben 1892 bzw. I8II (Abschrift aus Archiv-Nr. 22IO. Ev.-luth. Kirchgemeinde Riesa).

von Welck A.F. (1992), Lebensbilder, $2^{\text {nd }}$ ed., Bad Godesberg. 
von Welck C.R.F. (I828), Acta die herrschaftliche Gruft betreffend. Ergangen in den Jahren I828 (Abschrift aus Archiv-Nr. I854 A. Ev.-luth. Kirchgemeinde Riesa).

von Welck S.F. (2019), Die Familie der Freiherren von Welck, "Sächsische Heimatblätter", 65 (3), p. 247-25I.

\section{Summary}

\section{Crypt Burials from the Cloister Church of Riesa (Germany) - Changes of Funerary Customs, Body Treatment, and Attitudes to Death}

The cloister church of Riesa (Saxony, Germany) contains two burial crypts which were used from the $17^{\text {th }}$ to $19^{\text {th }}$ century AD by local noble families, namely the barons von Felgenhauer, Hanisch/von Odeleben and von Welck. The crypt beneath the altar originally contained 50 inhumations of which about 30 are still preserved at present, either as coffins and/or mummies, while the northern crypt contained eight interments.

During the last two centuries, the crypts have experienced major changes which could partly be reconstructed through historical records, photographs and oral history. The aim of the investigations, supported by the parish and the city museum, was to document the current state-of-preservation and to identify the inhumations by combining different types of evidence.

The coffins were visually inspected and dated by typo-chronological comparisons, and inscriptions were transliterated whenever possible. Material, fabrication, clothing type and dating of the garments were determined during costume analysis. The mummified remains were subjected to a morphological investigation, including X-rays. Different body treatments resulting in natural or artificial mummification could be observed. In selected cases, samples for aDNA analysis were taken to test for kinship between individuals, and stable isotope analysis was performed for the reconstruction of diet, origin and age of weaning. Probable identification could only be achieved for the individuals with contextual information; however, the bioarchaeological analyses are still ongoing.

The coffin ornamentation and inscriptions as well as the garments show chronological changes as well as individual preferences from the $17^{\text {th }}$ to $19^{\text {th }}$ century, most distinctive in the children burials. Faith in God and hope of resurrection remain constant attitudes to death, but familial affiliation becomes an important factor in early modern noble burials.

Keywords: crypt, burial, mummy, post-medieval, nobility

\section{Streszczenie}

Pochówki w kryptach z kościoła klasztornego w Riesie (Niemcy) - zmieniające się zwyczaje pogrzebowe, sposoby postępowania z ciałem i podejścia do śmierci

Kościół klasztorny w Riesie (Saksonia, Niemcy) posiada dwie krypty grobowe, wykorzystywane od XVII do XIX w. przez miejscowe rodziny szlacheckie, w tym baronów von Felgenhauer, Hanisch/von Odeleben oraz von Welck. Krypta pod ołtarzem pierwotnie 
zawierała 50 pochówków, z których 30 dotrwało do czasów współczesnych w formie trumien i/lub mumii, a krypta północna zawierała osiem pochówków.

Na przestrzeni ostatnich dwóch wieków w kryptach zaszły ogromne zmiany, które udało się po części zrekonstruować w oparciu o zapisy historyczne, zdjęcia oraz historię ustną. Celem badań prowadzonych przy wsparciu parafii i muzeum miejskiego było udokumentowanie obecnego stanu zachowania oraz identyfikacja pochówków poprzez łączenie różnych rodzajów dowodów.

Trumny zostały poddane inspekcji wzrokowej i datowane w oparciu o porównania typochronologiczne, a ponadto $\mathrm{w}$ miarę możliwości dokonano transliteracji inskrypcji. Materiały, sposób wytworzenia, typ i datowanie odzieży zostały ustalone w ramach analizy kostiumologicznej. Zmumifikowane szczątki poddano badaniom morfologicznym, w tym prześwietleniom rentgenowskim. Zaobserwowano różne sposoby postępowania z ciałem, prowadzące do naturalnej lub sztucznej mumifikacji. W wybranych przypadkach pobrano próbki do analizy DNA, aby sprawdzić stopień pokrewieństwa. Przeprowadzono też analizę izotopów stabilnych celem ustalenia diety, pochodzenia i wieku odstawienia od piersi. Prawdopodobną tożsamość można było ustalić wyłącznie w przypadku osób, dla których dostępne były informacje kontekstowe. Niemniej jednak trwają wciąż analizy bioarcheologiczne.

Zdobienia trumien i inskrypcje, jak również odzież odzwierciedlają zmiany chronologiczne oraz indywidualne preferencje z okresu od XVII do XIX w., co jest szczególnie widoczne w przypadku pochówków dzieci. Wiara w Boga i nadzieja na zmartwychwstanie pozostają stałymi elementami podejścia do śmierci, jednakże we wczesnonowożytnych pochówkach szlacheckich istotną rolę zaczynają odgrywać więzy rodzinne.

Słowa kluczowe: krypta, pochówek, mumia, czasy pośredniowieczne, szlachta

\author{
Amelie Alterauge \\ University of Bern \\ Institute of Forensic Sciences \\ Department of Physical Anthropology \\ \& \\ University of Bern \\ Institute of Archaeological Sciences \\ Department of Prehistory \\ Switzerland \\ e-mail: amelie.alterauge@iaw.unibe.ch
}

\title{
Cornelia Hofmann
}

Museums of the City of Dresden

Germany

e-mail: cornelia.hofmann@museen-dresden.de 